\title{
An empirical investigation on the effect of foreign investment on export development
}

\author{
Mahsan Hajirasouliha*
}

Department of Management, South Tehran Branch, Islamic Azad University, Tehran, Iran

\begin{tabular}{l}
\hline C H R O N I C L E \\
\hline Article history: \\
Received September 10, 2013 \\
Received in revised format \\
10 December 2013 \\
Accepted December 122013 \\
Available online \\
December 162013 \\
\hline Keywords: \\
Foreign direct investment \\
Export development \\
Business development
\end{tabular}

\section{A B S T R A C T}

\begin{abstract}
One of the methods to reach continuous improvement on economy is to boost export and target international market. However, there are some limits on available resources, which present most developing countries for improvement of export activities. One way to overcome such trouble is to use foreign direct investment but this may happen only when we could determine major barriers and overcome the challenges. The present study presents an empirical investigation to detect important barriers on foreign direct investment in Iranian industries. The proposed study uses structural equation modeling to detect major barriers for export development. The results of our survey indicate that there were four factors including economic factors, feasibility study, infrastructure for investment and investment resources influencing on foreign direct investment.
\end{abstract}

\section{Introduction}

Foreign direct investment plays essential role on building sustainable economy and creating suitable opportunity for export development (De Mello, 1999; Moosa, 2002; Carkovic \& Levine, 2002). There are various studies on learning the effect of foreign direct investment on economy. Borensztein et al. (1998) examined the impact of foreign direct investment (FDI) on economic growth in a crosscountry regression framework, utilizing data on FDI flows from industrial countries to 69 developing countries over the period 1978-1997. They results recommended that FDI was an important tool for the transfer of technology, contributing to growth than domestic investment. However, the higher productivity of FDI held only when the host country had a minimum threshold stock of human capital. Therefore, FDI could contribute to economic growth only when a sufficient absorptive capability of the advanced technologies had been available in the host economy. According to Lizondo (1993), there has been a rapid growth in global FDI flows, which increased from $\$ 47$ billion in 1985 to $\$ 139$ billion in 2001. Moran (2011) stated that FDI occurs when a corporation in one country builds a business operation in another one, through setting up a new wholly-owned affiliate, or acquiring a local company, or forming a joint venture in the host economy.

* Corresponding author.

E-mail addresses: mahsan_themoon@yahoo.com (M. Hajirasouliha)

(C) 2014 Growing Science Ltd. All rights reserved.

doi: $10.5267 /$ j.uscm.2013.12.002 
Javorcik (2004) investigated whether FDI could increase the productivity of domestic firms or not. The survey reported that spillovers were associated with projects with shared domestic and foreign ownership but not with fully owned foreign investments. Feenstra and Hanson (1997) investigated FDI and relative wages by looking into some evidence from Mexico's maquiladoras. Balasubramanyam et al. (1996) examined, within a new growth theory framework, the role which FDI played in the growth process in the context of developing countries characterized by differing trade policy regimes. Markusen and Venables (1999) investigated the effect of FDI as a catalyst for industrial development. Underwood (2012) investigated the substantial growth of FDI into the United States by international automotive firms over the past 25 years. The author studied Global macro-environmental factors impacting this investment, which were the resulting effects on numerous stakeholders including global automotive firms, consumers, and regional and state economies. The findings stated effective adaptive strategies that both automotive firms and economic development stakeholders follow in an increasingly global environment, resulting in substantial economic, market, and quality-of-life benefits.

\section{The proposed study}

The present study presents an empirical investigation to detect important barriers on foreign direct investment in Iranian industries. The proposed study uses structural equation modeling to detect effect of some major barriers. There are five hypotheses associated with this study as follows,

1. There is a relationship between economic factors and foreign direct investment.

2. There is a relationship between economic feasibility study and foreign direct investment.

3. There is a relationship between economic infrastructure for investment and foreign direct investment.

4. There is a relationship between incentive for investment and foreign direct investment.

5. There is a relationship between economic resources and foreign direct investment.

In order to accomplish the purpose of the present study, a questionnaire was designed and distributed amongst the 240 executives and chief managers of the foreign investment organizations in Iran. Collecting 200 questionnaires, the core data was analyzed using structural equation modeling.

\section{The results}

In this section, we present details of our findings on testing various hypotheses of this survey using structural equation modeling. Fig. 1 demonstrates the results of our findings in the first stage.

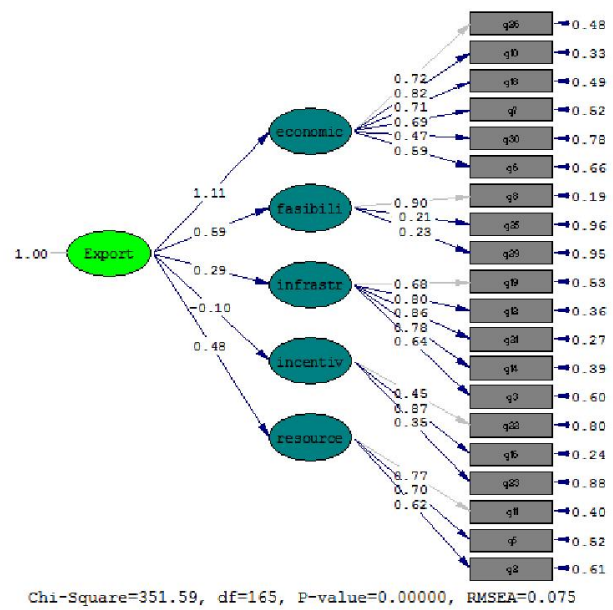

The results of standard data

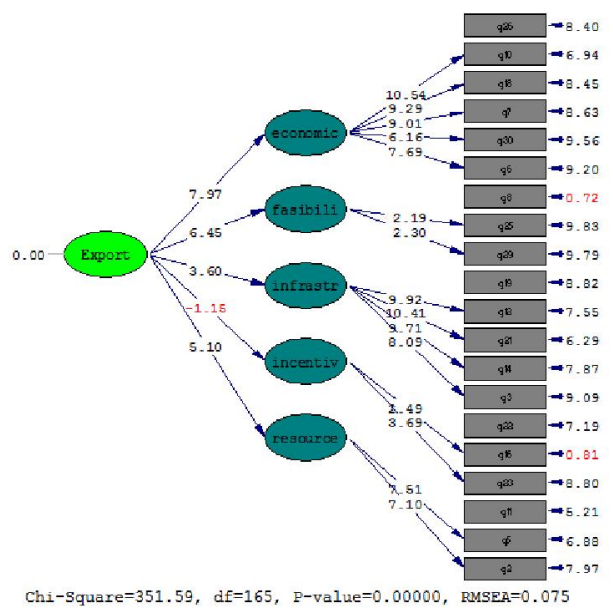

The results of t-values

Fig. 1. The preliminary results of the implementation of SEM 
As we can observe from the results of Fig. 1, four out of five components are statistically meaningful when the level of significance is five percent. Therefore, we have decided to remove the fourth item, incentive, from our survey and repeat the process one more time shown in Fig. 2 as follows.

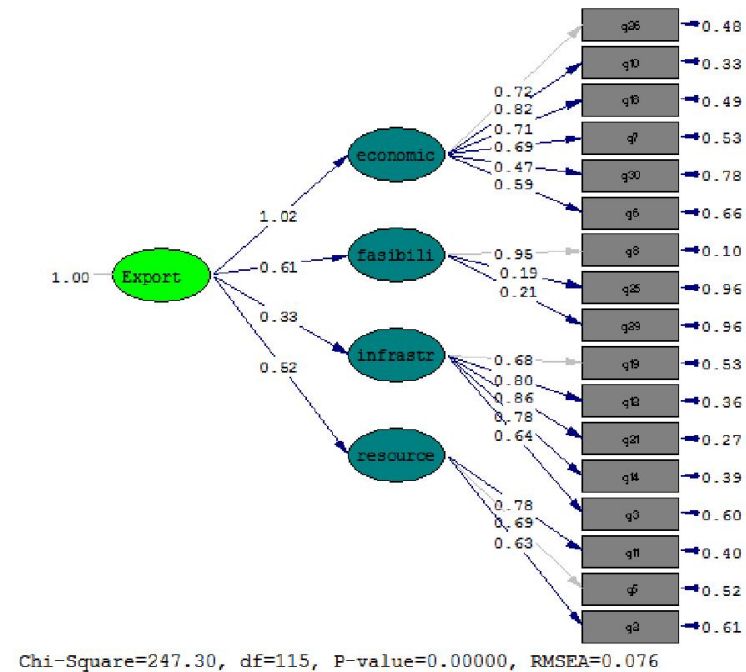

The results of standard data

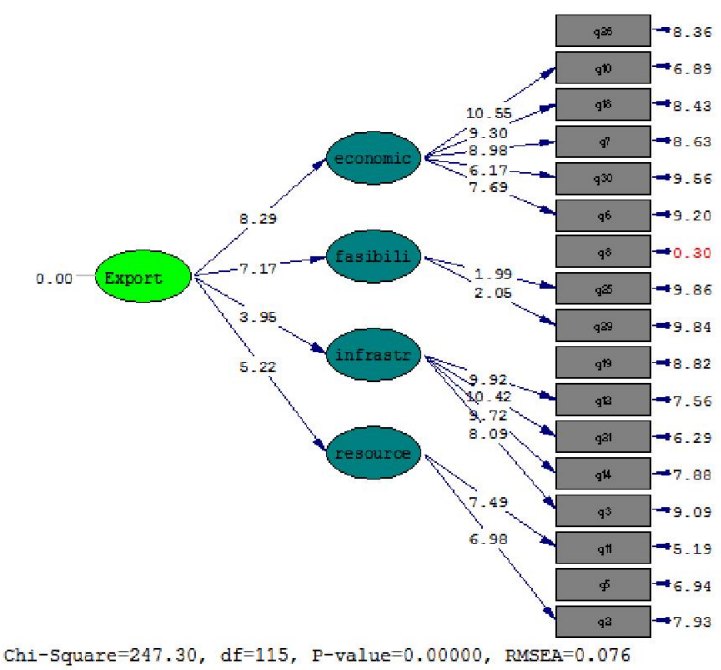

The results of t-values

Fig. 2. The results of the implementation of SEM

Table 1 demonstrates the summary of some basic statistics associated with SEM implementation.

Table 1

The summary of statistics on SEM implementation

\begin{tabular}{lcccccccc}
\hline Statistics & Chi-square/df & GFI & RMSEA & CFI & NFI & NNFI & GFI & AGFI \\
\hline Value & 2.15 & 0.93 & 0.076 & 0.93 & 0.88 & 0.91 & 0.97 & 0.83 \\
Index & $<3$ & $>0.9$ & $<0.09$ & $>0.90$ & $>0.90$ & $>0.90$ & $>0.90$ & $>0.80$ \\
\hline
\end{tabular}

As we can observe from the results of Table 1, all statistical data are within desirable limits, which validate the overall study. The results indicate that there were four factors including economic factors, feasibility study, infrastructure for investment and investment resources influencing on foreign direct investment.

\section{Conclusion}

In this paper, we have presented an empirical investigation to detect important factors influencing foreign direct investment in Iran. The proposed study has implemented structural equation modeling to determine important factors and the results indicate that there were four factors including economic factors, feasibility study, infrastructure for investment and investment resources influencing on foreign direct investment. The results of this survey are consistent with the results earlier presented by Hajirasouliha et al. (2014) using factor analysis.

\section{Acknowledgement}

The authors would like to thank the people who participated in our survey and contributed to this survey by their insights. 


\section{References}

Balasubramanyam, V. N., Salisu, M., \& Sapsford, D. (1996). Foreign direct investment and growth in EP and IS countries. The Economic Journal, 92-105.

Borensztein, E., De Gregorio, J., \& Lee, J. W. (1998). How does foreign direct investment affect economic growth?. Journal of international Economics, 45(1), 115-135.

Carkovic, M., \& Levine, R. (2002). Does foreign direct investment accelerate economic growth?. $U$ of Minnesota Department of Finance Working Paper.

De Mello, L. R. (1999). Foreign direct investment-led growth: evidence from time series and panel data. Oxford Economic Papers, 51(1), 133-151.

Feenstra, R. C., \& Hanson, G. H. (1997). Foreign direct investment and relative wages: Evidence from Mexico's maquiladoras. Journal of international economics, 42(3), 371-393.

Hajirasouliha, M., Heydari Kord Zanganeh, G., Hosseini Golafshani, S. A. (2014). The role of foreign direct investment on increasing the amount of export. Management Science Letters, 3(1), 101-106.

Javorcik, B. S. (2004). Does foreign direct investment increase the productivity of domestic firms? In search of spillovers through backward linkages. The American Economic Review, 94(3), 605-627.

Lizondo, J. S. (1993). Foreign direct investment. Readings in International Business: A Decision Approach, 85-114.

Markusen, J. R., \& Venables, A. J. (1999). Foreign direct investment as a catalyst for industrial development. European economic review, 43(2), 335-356.

Moosa, I. A. (2002). Foreign direct investment. Palgrave.

Moran, T. H. (2011). Foreign Direct Investment. Blackwell Publishing Ltd.

Underwood, R. L. (2012). Automotive foreign direct investment in the United States: Economic and market consequences of globalization. Business Horizons, 55(5), 463-474. 